\title{
Virus respiratorio sincicial humano A, genotipo Ontario
}

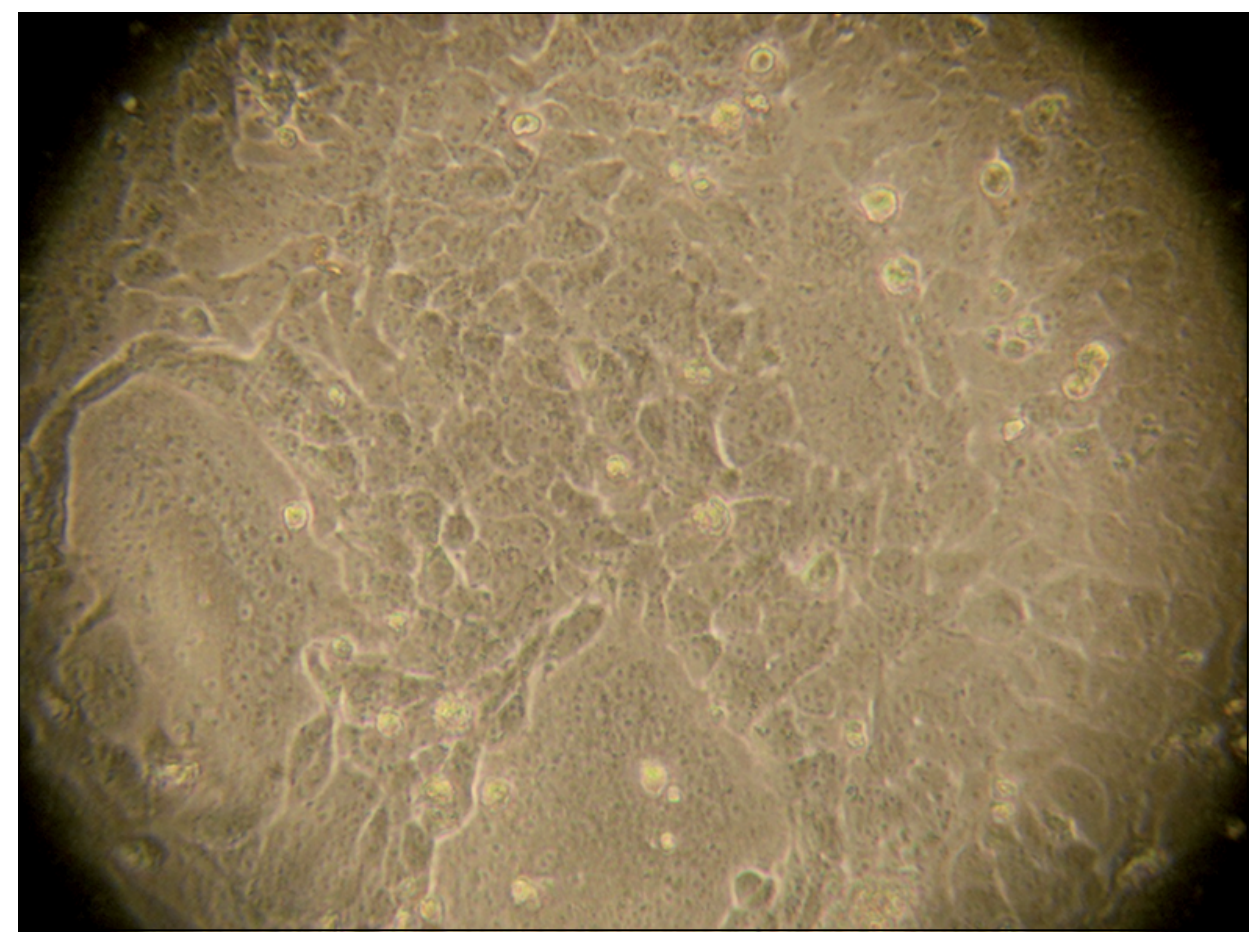

Figura 1. Aislamiento viral en células HEp-2. Efecto citopático característico de formación de sincicios visualizada bajo microscopio óptico 40X. Fotografía: Lorena Tapia, Programa de Virología. ICBM. Facultad de Medicina. Universidad de Chile. 


\title{
Virus respiratorio sincicial humano A, genotipo Ontario
}

Virus respiratorio sincicial (VRS) es miembro de la familia Paramyxoviridae, género Pneumovirus. Corresponde a un virus envuelto, de 100 a $300 \mathrm{~nm}$ de diámetro. Su genoma ARN negativo, de aproximadamente 15.000 nucleótidos, codifica para 11 proteínas. Mediante el análisis con anticuerpos monoclonales contra proteínas virales -especialmente antiproteínas de superficie G y F-, fue posible clasificarlo en dos grupos antigénicos, denominados VRS A y B. Posteriormente, el análisis nucleotídico de una región hipervariable del gen $\mathrm{G}$ permitió detectar múltiples variantes virales (genotipos) dentro de ambos grupos antigénicos. Hasta la fecha, se han descrito 12 genotipos en el grupo VRS-A (GA1GA7, SAA1, NA1-2 and ON1-2) y 20 genotipos en VRS-B (GB1-4, BA1-10, SAB1-4, and URU1-2). VRS-A genotipo Ontario (ON) fue descrito el año 2010 en Canadá. Su característica es presentar una duplicación de 72 nucleótidos (24 aminoácidos) en la región C-terminal del gen $\mathrm{G}$, algo similar a la duplicación de 60 nucleótidos que se describió el año 1999 en cepas VRS-B en Buenos Aires, Argentina (Genotipo BA). Interesantemente, tanto el genotipo BA como ON han reemplazado las demás cepas circulantes, habiendo sido Ontario detectado en al menos 21 países. En el Programa de Virología, del Instituto de Ciencias Biomédicas de la Universidad de Chile, lo hemos detectado y aislado desde el brote epidémico del año 2013 desde lactantes internados con bronquiolitis. Hasta la fecha, no se ha reportado asociación con una mayor gravedad en el cuadro clínico.

Su identificación, al igual que el resto de los VRS-A, se realiza mediante técnicas habituales desde muestras clínicas de secreción respiratoria. En lactantes y niños pequeños, las técnicas de detección de antígenos son las recomendadas dada su alta sensibilidad y bajo costo (inmunofluorescencia, inmunocromatografía, ELISA). En cambio, en adultos la recomendación es utilizar técnicas de amplificación del genoma viral (RPC-TR o plataformas de amplificación automatizadas), ya que este grupo etario excreta una menor cantidad de virus. La genotipificación se reserva para fines de investigación.

Agradecimientos: A M. Inés Espinoza por su apoyo técnico. FONDECYT de Iniciación a Investigación № 11121536.

\section{Referencias bibliográficas}

1.- Duvvuri V R, Granados A, Rosenfeld P, Bahl J, Eshaghi A, Gubbay J B. Genetic diversity and evolutionary insights of respiratory syncytial virus A ON1 genotype: global and local transmission dynamics. Sci Rep 2015; 5: 14268.

2.- Eshaghi A, Duvvuri V R, Lai R, Nadarajah J T, Li A, Patel S N, et al. Genetic variability of human respiratory syncytial virus a strains circulating in Ontario: a novel genotype with a 72 nucleotide G gene duplication. PLoS One 2012; 7: e32807.

3.- Luchsinger V, Piedra P A, Ruiz M, Zunino E, Martínez M A, Machado C, et al. Role of neutralizing antibodies in adults with communityacquired pneumonia by respiratory syncytial virus. Clin Infect Dis 2012; 54: 905-12.

\author{
Lorena Tapia, Natalia Alvial y Paula Bravo \\ Facultad de Medicina, Universidad de Chile \\ Programa de Virología, Instituto de Ciencias Biomédicas (LT) \\ Escuela de Medicina (NA, PB) \\ Correspondencia a: \\ Itapia@med.uchile.cl
}

